\title{
Publisher Correction: Genomic signatures of human and animal disease in the zoonotic pathogen Streptococcus suis
}

Lucy A. Weinert, Roy R. Chaudhuri, Jinhong Wang, Sarah E. Peters, Jukka Corander, Thibaut Jombart, Abiyad Baig, Kate J. Howell, Minna Vehkala, Niko Välimäki, David Harris, Tran Thi Bich Chieu, Nguyen Van Vinh Chau, James Campbell, Constance Schultsz, Julian Parkhill, Stephen D. Bentley, Paul R. Langford, Andrew N. Rycroft, Brendan W. Wren, Jeremy Farrar, Stephen Baker, Ngo Thi Hoa, Matthew T.G. Holden, Alexander W. Tucker \& Duncan J. Maskell, BRaDP1T Consortium

Correction to: Nature Communications https://doi.org/10.1038/ncomms7740, published online 31 March 2015.

The Supplementary Data 1-5 files associated with this Article are corrupted. The correct versions of Supplementary Data 1-5 can be found as Supplementary Information associated with this Correction. The error has not been corrected in the Supplementary Information associated with this Article.

Published online: 22 November 2019

\section{Additional information}

Supplementary Information is available for this paper at https://doi.org/10.1038/s41467-019-13138-w.

\section{BRaDP1T Consortium}

Janine T. Bossé, Yanwen Li, Gareth A. Maglennon, Dominic Matthews, Jon Cuccui \& Vanessa Terra

(c) Open Access This article is licensed under a Creative Commons Attribution 4.0 International License, which permits use, sharing, adaptation, distribution and reproduction in any medium or format, as long as you give appropriate credit to the original author(s) and the source, provide a link to the Creative Commons license, and indicate if changes were made. The images or other third party material in this article are included in the article's Creative Commons license, unless indicated otherwise in a credit line to the material. If material is not included in the article's Creative Commons license and your intended use is not permitted by statutory regulation or exceeds the permitted use, you will need to obtain permission directly from the copyright holder. To view a copy of this license, visit http://creativecommons.org/licenses/by/4.0/.

(C) The Author(s) 2019 